\title{
COMPLEMENTARITY AND SUBSTITUTION IN THE KNOWLEDGE NETWORKS OF R\&D SUBSIDIARIES
}

\section{Ulf Andersson, Suma Athreye and Georgios Batsakis}

\begin{abstract}
We argue that a foreign-based $R \& D$ subsidiary of a multinational enterprise (MNE) can potentially source knowledge from three diverse knowledge networks, namely (i) external knowledge network of the home country, (ii) external knowledge network of the host country, and (iii) internal (MNE) knowledge network. Drawing on the relative costs and benefits associated with the process of synergistic knowledge, this study examines whether a substitutive or a complementary relationship exists when two of the aforementioned networks collaborate in order to generate new knowledge at the subsidiary level. Our study's sample is based on a survey questionnaire addressed to foreign-based $R \& D$ subsidiaries of Fortune 500 companies. We assess the existence of complementarity/ substitutability using the "production function approach." Our results indicate that a complementary relationship exists between external knowledge network of the host and the home country, as well as between
\end{abstract}

\footnotetext{
Perspectives on Headquarters-Subsidiary Relationships in the Contemporary MNC

Research in Global Strategic Management, Volume 17, 247-274

Copyright $(\mathbb{C} 2016$ by Emerald Group Publishing Limited

All rights of reproduction in any form reserved

ISSN: 1064-4857/doi:10.1108/S1064-485720160000017010
} 
external knowledge network of the host country and internal knowledge network. On the other hand, external knowledge network of the home country and internal knowledge network form a substitutive relationship. Our study offers a more comprehensive view of the diverse sources/knowledge networks that $R \& D$ subsidiaries are sourcing knowledge from when compared to existing research. We also specify and account for the costs/benefits involved in knowledge sourcing and thereby detect possible substitution/complementarity between different sources of knowledge. So far, there has been limited to nonexistent research into the diversity of knowledge networks of $R \& D$ subsidiaries and the examination of potential substitutabilities and complementarities. Hence our empirical study contributes to the development of this particular research stream.

Keywords: Knowledge networks; knowledge sourcing; complementarity; substitution

\section{INTRODUCTION}

Extant research on knowledge and innovation management has shown the complementarity of different knowledge sources and how complementing the internal stock of knowledge with external (nonredundant) knowledge can increase the innovative performance, and indeed also financial performance, of the firm (Ambos, Nell, \& Pedersen, 2013; Burt, 1993; Kang \& Kang, 2009). The same holds for the multinational enterprise (MNE) subsidiary as well. Thus, the involvement of R\&D subsidiaries in the host country network of firms, institutions, and universities has been shown to impact the subsidiary's performance (Andersson, Forsgren, \& Holm, 2002; Figueiredo, 2011; Yamin \& Otto, 2004), and the parent MNE's competence development (Andersson, Forsgren, \& Holm, 2001; Nell, Ambos, \& Schlegelmilch, 2011).

Integrating knowledge from different geographical locations and subsequently exploiting this knowledge in different markets is also the raison d'être of the MNE (Grant, 1996; Kogut \& Zander, 1996). Research on international R\&D management has increasingly focused on interfirm relationships and network participation, and more specifically on subsidiary (relational embeddedness) in the host country context as an important vehicle for realizing knowledge development and innovation (Andersson, Björkman, \& Forsgren, 2005; Santangelo, 2012).

Although the majority of existing works in this area have focused exclusively on the R\&D subsidiary's relationships in the host country environment, other 
categories of technological and knowledge flows may also be important. For example, in their recent review paper, Michailova and Mustaffa (2012) classify extant research on knowledge flows to four different categories, depending on the focus of examination. From our perspective, one research strand points out that foreign-based subsidiaries are simultaneously embedded in two distinct knowledge networks, the MNE internal network of parent and affiliates and the external network of the host country (see e.g., Almeida \& Phene, 2004; Ambos, 2005; Phene \& Almeida, 2008). Another strand of studies shows that subsidiaries are simultaneously embedded in the host and the home (parent) knowledge networks (see e.g., Bas \& Sierra, 2002; Criscuolo, 2009). These findings are all couched in terms of dichotomies (external-internal, host-home), which of course simplify the lessons for technology and knowledge management, but also conceal important traits of the different possible networks a subsidiary can be sourcing knowledge from.

Such dichotomous relationships often obscure some element of the true picture facing the subsidiary in their operational context. In the case of the internal-external dichotomy, the relationships that the foreign subsidiary might have with universities and laboratories in the home country are assumed to be fully mediated by the parent, hence being part of the "internal" source. In the case of the home-host dichotomy, the focus is shifted to the parent and it is assumed that the host country links of parent (usually managed by the foreign subsidiary in that country) is nevertheless part of the parent's external links thus disregarding the internal link, which makes these relationships possible. Such miss-classification needs to be looked at more closely in order to detect the different sources" "true" contribution to MNE performance.

More importantly, the costs of sourcing knowledge from the different sources seem absent or understated in the prevailing dichotomized perspectives. Since both dichotomies seem to conclude a complementary relationship between the different pairs the implicit assumption seems to be that costs outweigh the benefits. Yet, maintaining links to all three sources of knowledge may not be costless for the R\&D subsidiary. As well, the kind of costs that come into play might differ. Thus, maintaining links with the external environments whether in the host or home country gives rise to knowledge dissipation costs as collaborations may disclose technological information valuable to competitors (Ghemawat \& Spence, 1985). On the other hand, engaging in the internal knowledge network of the MNE gives rise to coordination costs of various kinds that may take up valuable managerial time and resources. Miss-specification of the sources of knowledge which are also associated with an over- or under-estimation of the true costs 
of using one knowledge source or the other may not be a good basis for managerial practice. This is particularly important when the subsidiary has as its main task creating and developing technological knowledge.

In this study, we seek to remedy this lacuna in existing studies. To this end, we first develop a framework where we associate the source of knowledge to particular costs of coordination and leakage. From the point of view of the (foreign) R\&D subsidiary, the knowledge for their capability development can be sourced from three different networks (and locations). These are the host country sources of technology and knowledge, the MNE internal network of parent and affiliates, and the home country networks of knowledge and technology relationships - access to which are often (but not always) controlled by the parent. Consider for example the use of expatriates in foreign $R \& D$ subsidiaries; these expatriates certainly have their own contacts with external home country actors since working at the parent company. They will therefore also use these known sources of knowledge when needed in their "new" capacity as expatriates too, without necessarily involving headquarters (HQs) as a mediating actor. Similarly, recent research also suggests that firms use "Diaspora populations" for their links to the host country (Saxenian \& Hsu, 2001). It is said that the decision by Texas Instruments to set up its $R \& D$ subsidiary in Bangalore was prompted by senior management from Bangalore who understood the potential of the location for R\&D development.

Next, we assume that subsidiary managers and the HQ as informed agents will seek to assess if the benefits derived from accessing two sources together will be outweighed by the costs of undertaking such collaborations. A complementary relationship between any two sources of knowledge must occur when there is a net benefit from engaging with the two sources of knowledge together. However, a substitutive relationship may develop whenever the predicted costs outweigh the benefits due to the complementarities of knowledge sources. Recent empirical research draws on similar relationships and shows that MNE subsidiaries forming a substitutive relationship are likely to adopt less knowledge than their counterparts, which are under a complementary relationship (Andersson, Gaur, Mudambi, \& Persson, 2015). Hence it can be argued that there are costs and benefits that are taken into consideration under a state of collaborative knowledge generation between MNE units.

In this study, we develop a more detailed understanding of the costs of collaboration in order to assess the complementary or substitutive nature of the relationship between the different knowledge sources facing the subsidiary. Our empirical analysis reveals that knowledge from host locations and 
intra-MNE sources, as well as the external linkages at home and host locations do show complementarity in the sense that more of one leads to a better innovative performance due to the other. However, subsidiaries are likely to find that coordination costs outweigh the benefits of complementarity when they try to use the home country's external network together with the intra-MNE network. We conjecture that this may be because overtime the MNE internalizes the important home economy advantages into its internal network. Thus, $R \& D$ subsidiaries will probably tend to use the intra-MNE network where the costs of dissipation to third parties are lower.

Our contribution to the literature is threefold. First we offer a more comprehensive view of the different sources that R\&D subsidiaries are sourcing knowledge from when compared to existing research. Second, this comprehensive specification of the knowledge sources enables us to specify and account for the costs involved in knowledge sourcing and thereby detect possible substitution between different sources of knowledge. Third, we show why internal knowledge networks are so important for the R\&D subsidiary. Apart from introducing coherence, the internal network allows the R\&D subsidiary to tap into those home country advantages that are most useful for the operation of the MNE. Successful internalization by the MNE ensures that overtime home country advantages are available through the internal network for the benefit of all subsidiaries.

The remainder of the chapter is organized as follows. Next section reviews the relevant literature in order to draw the hypotheses regarding the relationship between the three forms of subsidiary knowledge sourcing. The third section presents the methodology employed and data used for the assessment of potential complementarity/substitutability among the three forms of R\&D subsidiary knowledge sources. Subsequently we present the findings of the econometric analysis. Thereafter we discuss the findings, their implications, limitations; propose potential areas for future research; and draw conclusions.

\section{LITERATURE REVIEW AND HYPOTHESES DEVELOPMENT}

\section{Costs of Knowledge Sourcing in External and Internal Networks}

When striving to tap into different knowledge sources for better performance of the firm, the R\&D subsidiary relies on forming mutually beneficial relationships with the three sources of knowledge. These relationships 
also encounter different types of costs. A schematic model on where these types of costs emanates can be seen in Fig. 1. Relationships with external sources (whether in the home or in the host location) always contain the risk of leaking proprietary knowledge that might hurt the MNEs' competitive position, not only at the single subsidiary's level, but also at the level of the firm. Overtime however, the firms learn to internalize the learning from external home and host sources, and in Fig. 1 we show this in the expansion of the internal knowledge base of the firms.

Analysis of patent data strongly supports a conjecture of internalization of home country advantages. For example, Di Minin and Palmberg (2007) examine the home and foreign patenting of four multinational wireless telephony firms (Ericsson, Motorola, Nokia, and Qualcomm) and find that the essential patents held by these firms are more likely than other patents to have originated in the firm's HQ country. ${ }^{1}$ The authors argue that such a strong home country effect in the holding of essential patents occurs both because there is inertia in the organization of a firm's R\&D and also because more strategic $\mathrm{R} \& \mathrm{D}$ is likely to be conducted at home.

It is known that the extant knowledge sourced from other intra-MNE units can bring the subsidiary to a position where it can achieve high efficiency in a shorter time span (Hansen, 2002). Drawing on the internal network of subsidiaries however entails coordination costs. The MNE will pay attention to coordination costs originating from the duplication of activities or sourcing of the same knowledge from different sources. Such costs will appear when subsidiaries are simultaneously sourcing knowledge from

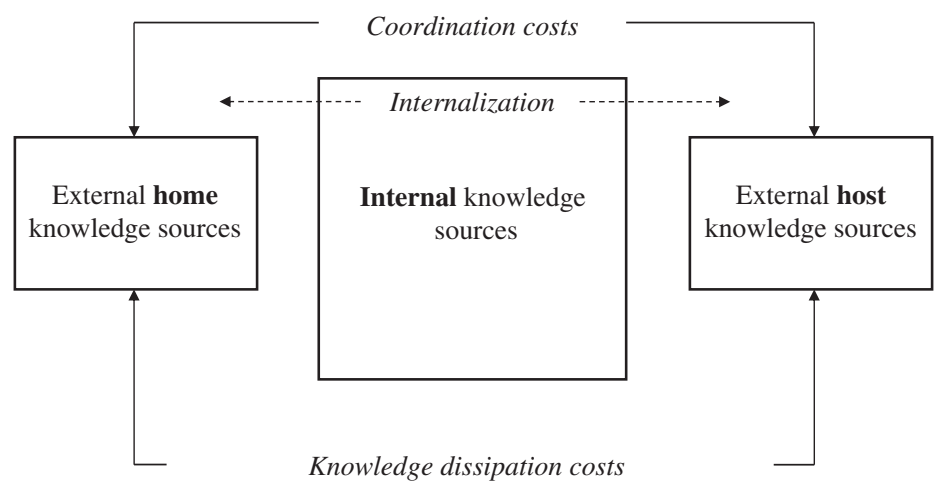

Fig. 1. Coordination and Knowledge Dissipation Costs between the Examined Forms of Knowledge Sourcing. 
the two external sources. Another type of coordination cost is ensuring that the relevant market information is combined with the technological information produced in the R\&D unit. Patel and Pavitt (1991) noted this as the most important coordination cost which prevented $R \& D$ from becoming more internationalized. Lastly, as pointed out by Bartlett and Ghoshal (1999), there is a need to consider the complexity of the knowledge being exchanged. Locating where the complex knowledge is can be an effective strategy if either market or technological information is complex. However, in cases where market and technological information are complex there may need to be greater rotation of people and roles. In turn, this can make the cost of coordination more complex and contingent on the willingness of key people to move.

In assessing whether to source knowledge from two networks simultaneously, firms will choose to evaluate if the benefits of pooling knowledge across two sources yield a larger benefit than the costs that such joint participation entails. When such net benefits are visible the two forms of knowledge networks (sources) are complementary. However, when such net benefits are not visible the $\mathrm{R} \& \mathrm{D}$ subsidiary will tend to substitute one network for the other.

\section{The Relationship between the Two Forms of External Knowledge Sourcing}

Although the innovative activities of the leading MNEs have followed a more globalized route throughout the years (Cantwell, 1995), it is also known that MNEs internationalizing their R\&D activities usually locate them in technological fields where they are strong at home (Bas \& Sierra, 2002; Patel \& Vega, 1999). This fact underlies the common notion that innovative activities implemented in the home country confer huge competitive advantages for the MNE (Bas \& Sierra, 2002). The host location where the R\&D subsidiary is located can provide a network of resources and partners whose contribution (knowledge) is likely to complement the existing knowledge derived from the home location of the MNE. Empirical evidence for this proposition comes mainly from the study of patent citation data drawn from European and US MNEs (Criscuolo, Narula, \& Verspagen, 2005). Likewise, Criscuolo (2009) argues that substituting home with host location's national system of innovation (NSI) carries significant negative drawback for the whole MNE (e.g., knowledge spillovers to competitors in the host location). More recently, D'Agostino and Santangelo (2012) showed that R\&D subsidiaries of OECD-based firms with a pure 
adaptation profile tend to complement host R\&D with home region knowledge creation.

We argue that foreign-based $R \& D$ subsidiaries will simultaneously rely on both forms of external knowledge (i.e., home and host). We draw on this argument for two main reasons. First, overseas subsidiaries will keep on carrying synergies from the home country's network to the host location. This is likely to happen since the parent firm has long-established partnerships with actors established in the home location, rather than in the host one. Accordingly, we argue that the subsidiary will be dictated by the HQs to retain these relationships. This will be the case even when the affiliate unit is based in a foreign, long-distanced location. Second, the overseas subsidiary will equally need to establish relationships with actors located in the host environment, either for research- or market-related reasons. As a result, we may expect that the two external networks - home and host - will have a complementary relationship and firms that are strongly embedded at home may also be strongly embedded in the host economy. Accordingly, we hypothesize that:

H1. External knowledge network of the home country and external knowledge network of the host country in which foreign R\&D subsidiaries are embedded will form a complementary relationship.

\section{The Relationship between External (Home and Host) and Internal Knowledge Sourcing}

The relationship between R\&D subsidiaries' internal and external knowledge networks on the other hand appears to be a bit more ambiguous. Foreign-based R\&D subsidiaries are less likely to hold inimitable knowledge assets that cannot be replaced by similar amount and quality of knowledge from the rest of the MNE internal network, or from the external environment. At first glance, this argument holds even more for subsidiaries, which have limited years of operation in the host economy, and consequently it is less likely that they have already developed a high level of independence from the federated network. This kind of subsidiaries is expected to rely heavily on internal knowledge sources.

On the other hand, and based on the resource dependency point of view, as subsidiaries grow and gain more experience and power through their longtime establishment in the host environment, it is likely that they will be in position to establish stronger ties and absorb more knowledge from 
the external network. Hence after a certain point these R\&D subsidiaries could rely more on external knowledge sources and less (or even not at all) on internal sources of knowledge. Cantwell and Mudambi (2005) argue that in the case of competence-creating subsidiaries, internal knowledge may over time show a U-shape, with internal knowledge rising again as the subsidiary grows in competence. Gammelgaard and Pedersen (2010) studying the relationship between internal and external knowledge sourcing provide support for this argument. Precisely, they research on subsidiary's sources of knowledge and find that the relationship between those two forms of knowledge (i.e., internal and external) is initially complementary, but is transformed to a substitutive one when the subsidiary's resource constraints become predictable and binding. These resource constraints in turn lead the R\&D subsidiary to a more tied relationship with only one of the two networks.

Although the relationship between external (either home or host) and internal sources of knowledge is not unambiguous, there is evidence supporting a complementary relation among external and internal knowledge sources. Studies conducted from a strategic alliance perspective (Kumar \& Nti, 1998; Nielsen, 2005), as well as from a technology management point of view (Audretsch, Menkveld, \& Thurik, 1996; Cassiman \& Veugelers, 2006; Foss \& Pedersen, 2002; Veugelers, 1997) confirm the positive link between these two forms of knowledge sourcing. Recent research on the relationship between the role of R\&D subsidiaries and their dual embeddedness shows that R\&D subsidiaries whose role evolves to a competencecreating mandate are likely to seek for a simultaneous growth regarding their degree of embeddedness in both internal and external networks (Achcaoucaou, Miravitlles, \& León-Darder, 2014). Likewise, evidence from domestic (noninternationalized) enterprises shows that internal and external resources form a complementary relationship that enhances the firm's absorptive capacity as regards the external knowledge acquisition (Hervas-Oliver \& Albors-Garrigos, 2009). From a different perspective, Lee, Lee, and Pennings (2001) amalgamated two fundamental theories, the resource-based view (RBV) and social capital (SC) theory in their attempt to explain entrepreneurial wealth creation. The findings suggest that both form a complementary relationship, since the one (i.e., SC) is valuable if and only if a firm is endowed with the other (i.e., internal capabilities). Taking into consideration that firm's internal capabilities are closely related to internal knowledge sourcing, as well as that SC is associated with the external knowledge acquisition, the above findings provide useful information in our attempt to explain the relationship of the three forms of knowledge sourcing. 
Our conjectures are based on the notion that external knowledge sourcing of the foreign-based R\&D subsidiary is divided to two distinct environments. These are the home and the host locations. First, concerning external host and internal knowledge sourcing, we trust that $R \& D$ subsidiaries will not be able to entirely substitute the internal knowledge with an equivalent amount of knowledge that is available in the host economy, mainly because such a strategy is possibly associated with a high degree of exposure to third parties characterized by a mutual interest. Even when the subsidiary is located in a well-protected (e.g., IPR protection regime) environment, knowledge spillovers are likely to occur, mainly because of the coexistence of highly competitive firms in the same cluster. Furthermore, although knowledge may be highly internalized due to possible knowledge spillovers in weak IPR protection regimes (Zhao, 2006), the subsidiary will always need to make use of external channels and related facilities, which are vital for its day-to-day operations. Accordingly, we formulate the following hypothesis:

H2. External knowledge network of the host country and internal knowledge network in which foreign R\&D subsidiaries are embedded will form a complementary relationship.

Regarding the relationship among home external and internal knowledge sourcing, we speculate that such a relationship is more likely to evolve into a substitutive one. The literature so far has shown that foreign-based R\&D subsidiaries are not very likely to become highly independent of their parent and affiliate units, unless they have developed technological competences, which are inimitable and highly valuable to the rest of the MNE network (Mudambi \& Pedersen, 2007). At the same time, ceteris paribus, the parent organization has much greater possibilities to source knowledge from external actors in the home country (due to proximity) when compared to the subsidiary. The parent might also already have the knowledge sought by the subsidiary and their ability to detect duplicate knowledge sourcing is much greater when it happens in their "backyard."

Taking into consideration that subsidiaries will always rely on the parent company (either for basic or less important needs) which is highly embedded in the home location's environment, and due to the coordination costs and inefficiency of sourcing knowledge from external home country actors when the parent country might already have "easy" access to knowledge from external counterparts located in the home country, we conjecture that there will be a substitutive relationship between the internal and external home knowledge sourcing of the subsidiary (Fig. 2). Accordingly, we formulate our hypothesis as follows: 


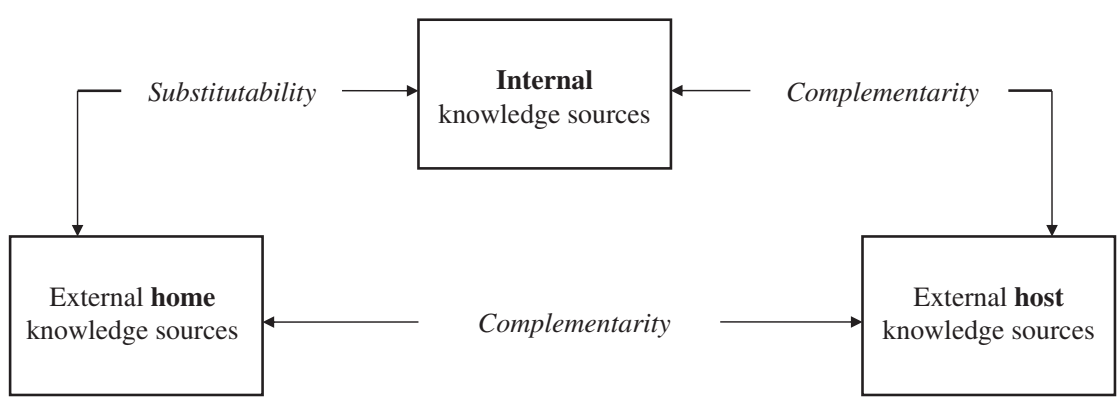

Fig. 2. Conceptual Schema: Complementarity and Substitutability between the Examined Forms of Knowledge Sourcing.

H3. External knowledge network of the home country and internal knowledge network in which foreign R\&D subsidiaries are embedded will form a substitutive relationship.

\title{
METHODS AND DATA
}

\author{
Methodology
}

Carree, Lokshin, and Belderbos (2011, p. 263) note that "there are two econometric approaches used to test for complementarity, viz. the 'adoption' or 'correlation' approach and the 'production function approach'." The first, due to Arora and Gambardella (1990), is applied by testing conditional correlations of the produced residuals based on (restricted form) regressions. An important issue that undermines its validity is that the correlated residuals may be a product of various measurement errors or omitted variables. Thus, the main drawback of this method is that it only tests complementarity of practices and not substitutability. This is due to the fact that the error terms can be contaminated by other unobservable effects.

The production function approach uses exclusive combinations of practices (strategies) as independent variables and measures the impact of the former on any chosen output measure. ${ }^{2}$ The approach is based on the common understanding of complementarities in production economics, which is that two inputs are complementary if more of one input increases the marginal productivity of the second input (Milgrom \& Roberts, 1990). This 
technique was suggested by Athey and Stern (1998), and was refined further for use in innovation studies by Belderbos, Carree, and Lokshin (2006) and Carree et al. (2011). The methodology used in this study draws upon Carree et al. (2011).

The output of knowledge sourcing we consider is the innovative performance (i.e., innovation output) produced within the R\&D subsidiary. Thus, we assume that the subsidiary maximizes its innovative performance $f(\mathbf{X}, \mathbf{Z})$, with respect to the vector of all possible combinations of three knowledge sourcing practices, $\mathbf{X}=$ (external home, external host, internal) and a number of control factors $\mathbf{Z}{ }^{3}$ Accordingly, the complete technology production function of our study can be written as follows:

$$
\operatorname{Ln}\left(\text { Patents }_{i}+1\right)=a+\sum_{r=0}^{1} \sum_{s=0}^{1} \sum_{t=0}^{1} \beta_{r s t} K_{\left(x_{1}, x_{2}, x_{3}\right)}=(r, s, t)+\beta Z_{i}+\varepsilon_{i}
$$

where $\varepsilon \sim\left(\sigma_{\varepsilon}^{2}\right)$, Ln (Patents ${ }_{i}+1$ ) is the subsidiary's production of innovation measured as the total number of patent counts issued to the R\&D subsidiary within a 5-year window $(t+5)$, where $t$ is the point where the knowledge sourcing is observed. $\mathbf{Z}$ is a vector of other control factors at the subsidiary-, country- and industry-level that are expected to have an impact on subsidiary's innovative performance, and $\varepsilon$ an error term.

The vector $\mathbf{X}$ consists of $x_{1}, x_{2}$ and $x_{3}$, which refers to the three unique knowledge sourcing practices (i.e., external home $\left(x_{1}\right)$, external host $\left(x_{2}\right)$, and internal $\left(x_{3}\right)$ ), and the indicator function $\mathbf{K}$ indicates all exclusive combinations of knowledge sourcing practices coefficients. The coefficients $\beta$ indicate the performance impact of adopting a particular sourcing practice or a combination of the three possible sources of knowledge.

The above technology production function acts as the basic model. In order to test the hypothesized complementarity/substitutability we first need to proceed to multiple inequality restrictions based on the "supermodularity theory" (Milgrom \& Roberts, 1990, 1995). In our case, and in order to test whether presence of complementarity or substitutability is observed for the exclusive combinations of knowledge sourcing practices, we need to estimate three different versions of the aforementioned model using maximum-likelihood estimation; an unconstrained model and two models with imposed inequality constraints (i.e., one with greater than or 
equal restrictions and another with less than or equal restrictions). Finally, in order to test for or against complementarity we proceed to a likelihoodratio (LR) test between the unconstrained and the constrained models.

\section{DATA}

We had great problems finding data that included all three sources of knowledge and the associated measures of embeddedness. The only available data that actually ask questions about all three sources of knowledge is the University of Reading survey of the Internationalization of $R \& D$ conducted in 1989 (described in Athreye, Batsakis, \& Singh, 2016; Pearce \& Singh, 1992). The sampling frame of the survey consisted of the Fortune 500 list published in 1986 when only 405 of the 500 units had established R\&D facilities abroad. However, this was a period when internationalization of R\&D was just emerging as a growing phenomenon and this context must be borne in mind in interpreting our results. Specifically, during this period the volume of internationalized $R \& D$ was low and modern techniques involving virtual communication and teams did not exist. So our findings on host and internal interactions need to be interpreted with caution.

In the Reading survey a questionnaire was sent via post to the existing population of foreign-based $\mathrm{R} \& \mathrm{D}$ units, ${ }^{4}$ where the subsidiary's CEO or R\&D manager was responsible for providing answers to the survey's questions. Given that many of the returned questionnaires were suffering from missing values, only 67 of the responses could be fully utilized in the existing study. The survey targeted the MNE's largest international R\&D unit ${ }^{5}$ whose role was to support local marketing and/or engineering activities, or to be capable of advanced research by contributing in a globally integrated research program. Although this selection strategy may exclude a number of MNE's R\&D units, it ensures that the examined foreign subsidiary is also a strategic subsidiary.

The survey data distribution is quite representative of what we know about global research activity of MNEs in the late 1980s. Patent data analysis for the same period, such as this conducted by Patel and Pavitt (1991), has shown that the United States accounts for almost half of the global R\&D activity, with Japan and the United Kingdom following with large shares. In our survey sample, R\&D subsidiaries based in the United States, the United Kingdom, and Japan account for $71.4 \%$ of the total sample. Further, about $75 \%$ of it consists of R\&D subsidiaries in pharmaceuticals, 
electronics, and chemicals and petroleum sectors - which are among the most internationalized sectors concerning R\&D activities.

\section{Nonresponse Bias and Common Method Bias}

We test for possible nonresponse bias and common method bias in our sample in several ways. First, we compare the number of respondents to that of the original population for all the examined geographical locations. Almost all the foreign locations where R\&D subsidiaries operate are well represented in the returned questionnaires, except for Canada and France, which are underrepresented. Second, since some questionnaires were collected after respondents received a second notice (reminder), we test for a possible nonresponse bias that may negatively affect our sample's explanatory power. Following Armstrong and Overton, 1977, we compared subsidiaries' age and size characteristics in the responses collected under first and second attempt and found no statistically significant difference between the two groups. Finally, in order to test if a common method bias had inflated the relationships between the variables used in the analysis, we used the Harman's single-factor test on the items included in our model (Podsakoff \& Organ, 1986). The factor analysis extracted four factors with eigenvalues greater than 1 , while the first one explains $21.12 \%$ of the total variance (eigenvalue $=4.37$ ). These results reject the presence of a single emerging factor, and also confirm that no factor accounts for the majority of the variance $(>50 \%)$. Thus, the survey data we use are reliable and common method bias is not a major issue.

\section{Variables}

\section{Dependent Variables}

Innovative performance: The production function approach to complementarity requires an output measure of inventiveness based on knowledge sourced internally, externally, or in combination by firms. Although innovative performance can be assessed in many ways (e.g., utilizing financial data by adopting the ratio of $\mathrm{R} \& \mathrm{D}$ expenditures to total return on investment or sales, or implementing survey questionnaires under which the innovativeness of the company was evaluated by the response of a general manager or CEO), patent count data are perceived as a more objective measure of true inventiveness of firms in new product and new technology 
generation (Hagedoorn \& Cloodt, 2003). Patent data have been used as an output proxy of subsidiary inventiveness in several studies (e.g., Almeida \& Phene, 2004; Phene \& Almeida, 2008; Sampson, 2007). More specifically, the measure of innovative performance we use is the total number of USPTO patents issued to the R\&D subsidiary within a 5-year window from the time the Reading survey was conducted. ${ }^{6}$ Since the survey was conducted in 1989, then the 5-year window corresponds to the period 01/01/1989-31/12/1993.

\section{Independent Variables}

The knowledge sourcing variables: We developed three measures of knowledge sourcing from the survey instrument. Two of these are measures of external knowledge sourcing and one of internal knowledge sourcing. The survey instrument asked respondents to provide information on the frequency of the subsidiary's contact with their internal and/or external knowledge sources using a 3-point Likert-scale, ranging from no contacts (1) to regular contacts (3) between the two interacted parties. In total three variables were constructed, namely external home $(\alpha=0.65)$, external host $(\alpha=0.60)$, and internal $(\alpha=0.73)$. The questions used for each construct are presented in Table 1. In order to adjust our data to the specific assumptions of the econometric method, we transformed the upper three scale variables to dichotomous ones. ${ }^{7}$ Since the original scaling of these variables ranges from "1" (weak) to " 3 " (strong) we transformed all the variables with values lower than " 2 " to " 0 ", and the variables with values equal or greater than "2" to "1". Hence, the newly constructed variables take the value " 1 " when a rather frequent to strong relationship with other sources of knowledge exists. On the other hand they are valued with " 0 " when a quite infrequent to none sort of relationship with other sources of knowledge is observed.

\section{Control Variables}

We use a number of subsidiary level controls that are indicated by literature on the subject of subsidiary innovativeness. The mandate of the subsidiary is clearly an important variable for the study. The questionnaire asks each R\&D subsidiary to classify its activities (using again a 3-point Likert-type structure) into the following three categories: Support Laboratories (SLs), Locally Integrated Laboratories (LILs), and Internationally Integrated Laboratories (IILs). Furthermore, we construct a variable for measuring the degree of R\&D subsidiary's centralization to the HQ. Following previous studies (e.g., Birkinshaw \& Hood, 2000; Nell \& Andersson, 2012), we use a 
Table 1. Operationalization of Variables.

Variables $\quad$ Questions Used from the Questionnaire in Order to Construct
Multi-Item Variables
External home "Does any liaison exist between this R\&D unit and the home country: (a) research institutions; (b) universities; and (c) R\&D labs of local and/or foreign companies?" The answers to this question have a categorical-Likert operationalization, ranging from 1 (no contacts reported) to 3 (regular contacts reported).

External host “(i) Does this R\&D unit give contract jobs to the following institutions in this country: (a) independent research labs; (b) universities; (ii) Does any exchange program of scientists exist between this unit and other local research institutions/labs? (iii) Are seminars relating to ongoing research in this unit held in collaboration with other local research units/institutions? (iv) Are research findings of this unit published in journals? (v) Are local independent researchers one of the most likely sources of project ideas initiated in this unit?" The answers to all the above questions also have a categorical-Likert formation, based on the frequency of interaction, and range from 1 (never) to 3 (regularly).

Internal "Are the parent or other sister R\&D units involved in your projects in any of the following ways? (i) systematic coordination of your projects into wider programs; (ii) to bring about a major change in the direction of the project; (iii) to advise on the development of a project; (iv) technical assistance at the request of the R\&D unit." The answers to all the above questions also have a categorical-Likert formation, based on the frequency of interaction, and range from 1 (never) to 3 (regularly).

Centralization "(i) Are promising projects shifted to parent or other strategic labs of the group around the world? (ii) Does this and other R\&D units of the parent company interact?" The answers to both questions range from 1 (never) to 3 (regularly). "(iii) If the unit has grown in size over time has this been (a) mostly as a result of its own success; (b) because of its own success and parent's encouragement; (c) mostly at the encouragement of the parent. (iv) How do you perceive the strategy of the parent towards its various R\&D units? (a) Allowing substantial autonomy; (b) Allowing them to develop independent initiatives, but under close central scrutiny; (c) Incorporating their work into a carefully coordinated programme."

Local "Which conditions or circumstances do you consider have most influenced endowment recent decisions with regard to the development of this unit? (i) a distinctive local scientific, educational, or technological tradition conducive to certain types of research project; (ii) presence of a helpful local scientific environment and adequate technical infrastructure; (iii) availability of research professionals; (iv) favorable wage rates for the research professionals." The answers to the above questions have a categoricalLikert formation, based on the frequency of interaction, and range from 1 (never) to 3 (regularly). 
multi-item scale for this measure. The Centralization construct $(\alpha=0.51)^{8}$ is based on four 3-point Likert-type questions. The items included decisions regarding shift of projects to parent or other strategic labs and the level of interaction with them, the general decentralization strategy of the parent towards its foreign affiliate unit, and growth dependence of the R\&D lab. We also include the subsidiary's mode of entry (Greenfield), size (LnSize), and age (LnYears) - all obtained from the survey questionnaire.

We also incorporated several industry dummies to control for the parent firm's field of operation and included traditional aggregate measures, such as Geographic Distance (e.g., Monteiro, Arvidsson, \& Birkinshaw, 2008) and Cultural Distance (Kogut \& Singh, 1988) of the R\&D subsidiary as factors capable of influencing the subsidiary's innovativeness. We further introduce a variable named Local endowment to control for the host location's endowment richness (i.e., local scientific and technological resources, scientific environment and technical infrastructure, availability of research professionals, and favorable wage rates for research professionals). This variable was also created from the survey questionnaire. Finally, we included two home country dummies for two of the most internationalized countries (in terms of R\&D activities) of our sample (United States and United Kingdom). Table 2 summarizes the variables created, provides information about their source, as well as it presents basic descriptive statistics for each of the variables.

\section{FINDINGS}

Our sample seems quite representative of the R\&D subsidiaries in the early 1990 s. In fact, $68 \%$ of the sample consists of production subsidiaries, with support labs emerging as the most popular mandate. The average level of centralization of R\&D decisions is high. The average age of an R\&D subsidiary in the sample was 26.2 years and the average R\&D employment size was 154.3 people. The raw scores (untransformed into dichotomized variables) suggest that the extent of home country knowledge sourcing is higher than its host country equivalent, though a slightly smaller number of firms seem to report the opposite.

Considering that survey data are prone to multicollinearity between the variables and the constructed factors we estimated the variance inflation factors (VIFs) for each coefficient in each examined model. The VIFs scores for the coefficients of the technology production function model 
Table 2. Variable Operationalization, Data Sources, and Descriptive Statistics.

\begin{tabular}{|c|c|c|c|c|c|c|c|c|}
\hline Variables & $\begin{array}{l}\text { Number of } \\
\text { Items Used }\end{array}$ & $\begin{array}{c}\text { Cronbach's } \\
\text { Alpha }(\alpha)\end{array}$ & Source & Type & Mean & SD & Min & $\operatorname{Max}$ \\
\hline Ln (Patents +1$)$ & & & USPTO & Scale & 2.16 & 1.92 & 0.69 & 6.00 \\
\hline External home & 3 & 0.65 & Survey & Binomial & 0.44 & 0.49 & 0 & 1 \\
\hline External host & 6 & 0.60 & Survey & Binomial & 0.30 & 0.46 & 0 & 1 \\
\hline Internal & 4 & 0.73 & Survey & Binomial & 0.54 & 0.50 & 0 & 1 \\
\hline SLs & & & Survey & Categorical & 1.77 & 0.75 & 1 & 3 \\
\hline LILs & & & Survey & Categorical & 2.05 & 0.74 & 1 & 3 \\
\hline IILs & & & Survey & Categorical & 2.11 & 0.88 & 1 & 3 \\
\hline Centralization & 4 & 0.51 & Survey & Scale & 2.34 & 0.33 & 1.5 & 3 \\
\hline Endowment & 4 & 0.72 & Survey & Scale & 1.73 & 0.54 & 1 & 3 \\
\hline Greenfield & & & Survey & Binomial & 0.68 & 0.46 & 0 & 1 \\
\hline LnYears & & & Survey & Scale & 2.95 & 0.93 & 0.69 & 4.82 \\
\hline LnSize & & & Survey & Scale & 4.14 & 1.36 & 1.38 & 7.54 \\
\hline $\begin{array}{l}\text { LnGeographical } \\
\text { distance }\end{array}$ & & & CEPII database & Scale & 8.55 & 0.80 & 5.83 & 9.74 \\
\hline Cultural distance & & & $\begin{array}{l}\text { Own calculations } \\
\text { based on } \\
\text { Kogut and } \\
\text { Singh (1988) }\end{array}$ & Scale & 2.14 & 2.51 & 0.09 & 9.70 \\
\hline
\end{tabular}


range from 1.43 to 3.08 , indicating that multicollinearity is not a problem for our model (Hair, Anderson, Tatham, \& Black, 1998). Table 3 presents pairwise correlations between variables, while the last row reports the exact VIFs score for each of the variables.

Table 4 presents the estimation results of the unrestricted equation (based on technology production function). Regarding the explanatory power of the model, it seems that the incorporated variables explain a rather significant amount of variance, since the $R^{2}$ has a value of $50.9 \%$. The regression results in Table 4 seem to explain only a fraction of relationships regarding single or even combinative knowledge sourcing practices. Actually, the only significant values are observed on the combinative practice among external home, external host, and internal knowledge sourcing $\left(\beta_{111}=-2.121, p<5 \%\right)$. Regarding the other variables we find that innovative performance is enhanced if subsidiaries are larger $R \& D$ subsidiaries, while being a US or UK subsidiary does not seem to have a positive impact on the innovative performance of the unit. Given that the regression results in Table 4 are not directly related to our hypotheses, we do not focus on the significance of these effects on innovative performance. However, we are mostly interested in assessing the complementarity/substitutability test.

The complementarity test results (see Table 5) corresponding to the imposed inequality constraints show that these are supporting the conjecture of complementarity for two out of the three pairs of knowledge sourcing practices, while the assumption of substitutability (subadditivity) is in favor of the third pair. Specifically, the LR test turned out to confirm the argument of complementarity for the pairs of knowledge sourcing practices of (i) external home/external host and (ii) external host/internal. On the other hand, the third pair (external home/internal) of knowledge sourcing practices is indicated as substitutive one, since the relative LR test turned out to be significant between the unrestricted and restricted (assuming substitutability) models.

\section{DISCUSSION}

Extant literature has highlighted the benefits of obtaining knowledge from different sources (Cassiman \& Veugelers, 2006; D'Agostino \& Santangelo, 2012; Foss \& Pedersen, 2002). A particular trait of these studies is the dichotomization of the possible sources at hand for an R\&D unit in its sourcing efforts. We have argued that apart from limiting the amount of 
Table 3. Correlation Matrix.

\begin{tabular}{|c|c|c|c|c|c|c|c|c|c|c|c|c|c|c|c|c|c|c|c|c|c|c|c|c|}
\hline & & 1 & 2 & 3 & 4 & 5 & 6 & 7 & 8 & 9 & 10 & 11 & 12 & 13 & 14 & 15 & 16 & 17 & 18 & 19 & 20 & 21 & 22 & 23 \\
\hline 1 & Ln (Patents +1$)$ & 1 & & & & & & & & & & & & & & & & & & & & & & \\
\hline 2 & SLs & 0.21 & 1 & & & & & & & & & & & & & & & & & & & & & \\
\hline 3 & LILs & -0.08 & 0.12 & 1 & & & & & & & & & & & & & & & & & & & & \\
\hline 4 & IILs & -0.07 & -0.30 & -0.57 & 1 & & & & & & & & & & & & & & & & & & & \\
\hline 5 & Centralization & -0.02 & -0.21 & 0.39 & -0.40 & 1 & & & & & & & & & & & & & & & & & & \\
\hline 6 & Endowment & -0.01 & -0.17 & -0.23 & 0.33 & -0.18 & 1 & & & & & & & & & & & & & & & & & \\
\hline 7 & Greenfield & -0.05 & -0.04 & -0.16 & 0.27 & -0.28 & 0.21 & 1 & & & & & & & & & & & & & & & & \\
\hline 8 & ln_Size & 0.04 & -0.13 & -0.41 & 0.34 & -0.26 & 0.15 & 0.12 & 1 & & & & & & & & & & & & & & & \\
\hline 9 & ln_Years & -0.28 & -0.10 & 0.23 & -0.10 & 0.37 & -0.02 & 0.11 & 0.12 & 1 & & & & & & & & & & & & & & \\
\hline 10 & ln_Geo_Distance & -0.06 & 0.09 & 0.14 & -0.11 & 0.03 & -0.08 & 0.08 & 0.07 & 0.08 & 1 & & & & & & & & & & & & & \\
\hline 11 & Cultural distance & 0.17 & 0.09 & -0.03 & 0.07 & -0.08 & -0.10 & -0.19 & -0.14 & -0.38 & -0.02 & 1 & & & & & & & & & & & & \\
\hline 12 & US & -0.18 & -0.08 & 0.00 & -0.06 & 0.16 & -0.12 & 0.10 & 0.10 & 0.36 & 0.06 & -0.16 & 1 & & & & & & & & & & & \\
\hline 13 & UK & -0.24 & -0.04 & 0.21 & 0.02 & 0.13 & -0.09 & -0.04 & -0.00 & 0.04 & 0.00 & -0.15 & -0.38 & 1 & & & & & & & & & & \\
\hline 14 & $\mathrm{CP}$ & -0.01 & 0.23 & 0.03 & 0.04 & -0.25 & -0.00 & 0.11 & 0.02 & -0.04 & 0.32 & 0.00 & -0.14 & 0.20 & 1 & & & & & & & & & \\
\hline 15 & EC & 0.13 & 0.01 & -0.05 & -0.06 & -0.13 & 0.01 & -0.01 & -0.10 & -0.16 & -0.25 & 0.12 & 0.12 & -0.19 & -0.37 & 1 & & & & & & & & \\
\hline 16 & PH & 0.00 & -0.25 & -0.24 & 0.33 & 0.12 & 0.25 & 0.03 & 0.12 & 0.09 & -0.08 & -0.11 & 0.20 & -0.11 & -0.40 & -0.22 & 1 & & & & & & & \\
\hline 17 & $\beta_{100}$ & -0.00 & -0.06 & 0.16 & 0.03 & 0.15 & -0.05 & -0.07 & -0.08 & 0.12 & 0.13 & -0.02 & 0.04 & -0.06 & -0.16 & 0.13 & 0.20 & 1 & & & & & & \\
\hline 18 & $\beta_{010}$ & -0.20 & -0.13 & 0.09 & 0.04 & 0.05 & 0.00 & -0.16 & -0.08 & 0.12 & -0.01 & -0.01 & -0.04 & 0.29 & 0.11 & -0.09 & 0.07 & -0.08 & 1 & & & & & \\
\hline 19 & $\beta_{001}$ & 0.23 & 0.12 & 0.09 & 0.04 & -0.03 & -0.05 & 0.12 & -0.20 & -0.16 & 0.15 & 0.12 & -0.11 & -0.03 & 0.21 & -0.23 & -0.08 & -0.21 & -0.11 & 1 & & & & \\
\hline 20 & $\beta_{110}$ & 0.01 & 0.05 & 0.09 & -0.27 & 0.11 & -0.06 & -0.00 & -0.09 & -0.08 & 0.03 & 0.04 & -0.18 & 0.10 & -0.17 & -0.09 & 0.07 & -0.08 & -0.04 & -0.11 & 1 & & & \\
\hline 21 & $\beta_{101}$ & 0.09 & -0.07 & -0.22 & 0.08 & -0.10 & 0.15 & -0.05 & 0.05 & -0.14 & 0.03 & 0.07 & 0.08 & -0.11 & 0.22 & 0.02 & -0.13 & -0.11 & -0.05 & -0.14 & -0.05 & 1 & & \\
\hline 22 & $\beta_{011}$ & 0.13 & 0.09 & -0.05 & 0.07 & -0.03 & -0.09 & 0.10 & -0.06 & -0.08 & -0.32 & 0.02 & -0.03 & 0.04 & -0.08 & 0.24 & -0.10 & -0.16 & -0.08 & -0.21 & -0.08 & -0.11 & 1 & \\
\hline 23 & $\beta_{111}$ & -0.37 & -0.03 & -0.25 & 0.19 & -0.30 & 0.31 & 0.06 & 0.36 & 0.11 & 0.05 & -0.22 & -0.10 & 0.01 & 0.09 & -0.20 & 0.05 & -0.18 & -0.09 & -0.23 & -0.09 & -0.12 & -0.18 & 1 \\
\hline & VIFs & - & 1.53 & 2.31 & 3.08 & 2.57 & 1.64 & 1.57 & 1.64 & 1.98 & 1.43 & 1.44 & 1.99 & 1.79 & 2.44 & 2.31 & 2.51 & 2.00 & 1.6 & 2.55 & 1.52 & 1.93 & 1.83 & 2.71 \\
\hline
\end{tabular}

Note: Coefficients with values greater than 0.14 are significant at the $10 \%$ level of significance. 
Table 4. OLS Regression Estimates on Innovative Performance.

\begin{tabular}{lc}
\hline & Innovative Performance \\
\hline SLs & $0.405(0.310)$ \\
LILs & $-0.081(0.395)$ \\
IILs & $-0.363(0.382)$ \\
Centralization & $0.738(0.927)$ \\
Endowment & $0.025(0.490)$ \\
Greenfield & $-0.121(0.515)$ \\
ln_Size & $0.473^{* *}(0.174)$ \\
ln_Years & $-0.155(0.289)$ \\
ln_Geo_Distance & $-0.130(0.324)$ \\
Cultural distance & $-0.024(0.093)$ \\
External home $\left(\beta_{100}\right)$ & $-0.270(0.773)$ \\
External host $\left(\beta_{010}\right)$ & $-1.067(1.193)$ \\
Internal $\left(\beta_{001}\right)$ & $0.788(0.744)$ \\
External home, external host $\left(\beta_{110}\right)$ & $-0.531(1.164)$ \\
External home, internal $\left(\beta_{101}\right)$ & $0.414(1.005)$ \\
External host, internal $\left(\beta_{011}\right)$ & $0.371(0.759)$ \\
External home, external host, internal $\left(\beta_{111}\right)$ & $-2.121^{*}(0.835)$ \\
Industry dummies & Included \\
Major country dummies & Included \\
Constant & $0.712(3.923)$ \\
$R$-squared & 0.509 \\
\hline
\end{tabular}

Note: Levels of significance: ${ }^{* *} p<1 \% ;{ }^{*} p<5 \%$ (robust S.E. in parentheses).

Table 5. Tests for Complementarity/Substitutability between Different Forms of Knowledge Sourcing.

\begin{tabular}{lcc}
\hline & LR Test Complementarity $(\geq)$ & LR Test Substitutability $(\leq)$ \\
\hline External home and external host & $11.99^{* *}$ & 0 \\
External home and internal & 3.34 & $7.89^{*}$ \\
External host and internal & $15.95^{* *}$ & 3.33 \\
\hline
\end{tabular}

Note: Levels of significance: ${ }^{* *} p<1 \%$ and ${ }^{*} p<5 \%$.

sources available for obtaining new knowledge the dichotomization obscures the costs involved in knowledge sourcing. In this study we set out to study the phenomenon of complementarity and substitutability of different knowledge sources. Introducing a pertinent view of the different sources available from an R\&D subsidiary's point of view (internal, host external, and home external), rather than the internal-external, or home-host 
dichotomies prevalent in extant research makes it possible to better account for the costs involved in knowledge sourcing. We have studied the relationships in the context of foreign-based R\&D subsidiaries. Firms locate R\&D units in different countries to tap into local knowledge and utilize cost advantages in qualified labor (Athreye et al., 2016). Accordingly we have argued that the possible coordination costs and inefficiencies of sourcing knowledge will surface if we acknowledge all the sources from which an R\&D subsidiary can obtain new knowledge.

Through utilizing a production function approach, we were able to account for the substitutability or complementarity of specific combinations of knowledge sourcing. As was indeed confirmed from our study, the dichotomization of sources obscures the true traits of the sources at hand for an R\&D subsidiary obtaining knowledge.

Our findings show that sourcing knowledge from both internal (federated MNE network) and home external networks has a substitutive effect due to coordination costs and inefficiencies. The phenomenon of increased coordination costs implies that the subsidiary will have to maintain relationship with both the federated MNE and the home external knowledge networks, which are both, located in the home country. The simultaneous maintenance of ties is possibly associated to establishment of more advanced and complex coordination mechanisms, which in turn lead to increased costs for the MNE. Another possibility is that the simultaneous maintenance of ties with these two knowledge networks may produce duplicative effects, which are also detrimental for the MNE in terms of costs. As a result, after a certain point, where the coordination costs that mainly arise from the simultaneous maintenance of ties and the duplicative effects, the foreign-based R\&D subsidiary opt to substitute the one form of knowledge sourcing with the other. This argument can also be framed under the over-embeddedness lenses (e.g., Hagedoorn \& Frankort, 2008; Nell \& Andersson, 2012; Uzzi, 1997) where at a certain point the increasing network of interfirm relationships becomes too complex and interconnected, that diminishing returns of new information gains starts to occur. This is the point where the over-embeddedness costs (which results from the simultaneous maintenance of ties between the knowledge networks of home external and internal) push the subsidiary to substitute one form of knowledge sourcing with the other.

On the contrary, sourcing externally in both the home and the host knowledge network is complementary as is internal and host external knowledge network sourcing. This result implies that for an MNE it is of utmost importance that its subunits are sourcing knowledge from sources 
complementary to each other so that the coordination costs do not spoil the leverage effects of knowledge combinations.

As with the majority of existing empirical studies, this study has several limitations. First, our data are in cross-sectional rather than in panel formation. Accordingly, we were not able to observe whether our findings are consistent over time. The incorporation of a longitudinal study would be an efficient way to control for evolution of knowledge sourcing practices and their relationships over time. Second, the datedness of our data may be an additional limitation for our study, since some of the relationships could have been atrophied or overtaken by technology. This holds especially for internal knowledge sourcing, where recent advances in information technology can have improved the monitoring, control, and coordination mechanisms of subsidiaries' activities. However, we already know from the literature that the degree of embeddedness and the social relationships are slowly developed and equally slowly amended. The notion of social interaction is universal across time and strengthens rather than weakens with time, as trust plays a vital role on this relationship.

The incorporation of an additional form of knowledge source can be both beneficial and inspirational for future research aiming to examine the context of the foreign-based subsidiary and its relationship with surrounding knowledge networks. We are particularly keen to see future research that complements and widens the knowledge stemming from our findings and can contribute to our understanding of this research question. Accordingly, future research studies can potentially test for complementarities between knowledge sources that arise from an even more objective measure, such as co-patenting, co-inventions, etc. Furthermore, taking into consideration that the external knowledge network of the affiliate units' country of residence has not been taken into empirical examination under this study, we assume that there might be another possibility that the forms of knowledge sourcing can be augmented even more. The same applies when we view the internal knowledge network in terms of dichotomies (i.e., knowledge network of HQ and knowledge network of affiliate units).

\section{CONCLUSION}

Overall, the general view of the foreign-based R\&D subsidiary's networks of knowledge, as well as the accompanying empirical results, contribute to our understanding regarding the context under which the subsidiary seeks for combinative sources of knowledge. Furthermore, this study contributes 
in the extant IB literature by responding to recent calls for viewing the available knowledge networks beyond the classic single- or dual-dimensionality of embeddedness. A realistic depiction of the subsidiary's surrounding knowledge networks show that the forms of the subsidiary's knowledge sources are multiple and more complex compared to the existing dichotomization (as is also discussed in Meyer, Mudambi, \& Narula, 2011). As a result, the combination of these knowledge sources is characterized by an equally complex relationship, which this study has empirically examined.

\section{NOTES}

1. Essential patents are those defined by the European Telecommunications Standards Institute as essential to a telecommunication standard and these firms held 553 out of 834 such patents.

2. Although the production function approach is a well-respected estimation method it should be noted that there are several limitations characterizing it (see Carree et al., 2011, p. 266, for more information).

3. The complementarity/substitutability test requests the cross-derivative to be nonnegative for all possible cross-term interactions of practices (Carree et al., 2011). In our data, this was the case only when we used a dichotomous transformation.

4. The first questionnaires were sent out in October 1988 and the last ones in June 1989, while the first completed questionnaire was received back in November 1988 and the last one in August 1989.

5. The identification of the largest foreign R\&D subsidiary was made after consulting a number of the leading directories of $R \& D$ facilities and evaluating its size according to financial and employment characteristics.

6. Since we are interested in the patent activity of R\&D units located in multiple locations, we set up the search by using the assignee name (e.g., SIEMENS), the host invention location (e.g., United States), as well as the 5-year window for which we are interested in.

7. The transformation of these variables from scale to dichotomous ones was made after having extracted the already developed three factors (i.e., external home, external host, and internal).

8. Although the reliability score for this construct does not reach a high level of efficiency, Nunnally, Bernstein, and Berge (1967) suggested that a score ranging between 0.50 and 0.60 is considered as acceptable reliability.

\section{REFERENCES}

Achcaoucaou, F., Miravitlles, P., \& León-Darder, F. (2014). Knowledge sharing and subsidiary R\&D mandate development: A matter of dual embeddedness. International Business Review, 23(1), 76-90. 
Almeida, P., \& Phene, A. (2004). Subsidiaries and knowledge creation: The influence of the MNC and host country on innovation. Strategic Management Journal. 25(8-9), 847-864.

Ambos, B. (2005). Foreign direct investment in industrial research and development: A study of German MNCs. Research Policv, 34(4), 395-410.

Ambos, T. C., Nell, P. C., \& Pedersen, T. (2013). Combining stocks and flows of knowledge: The effects of intra-functional and cross-functional complementarity. Global Strategv Journal, 3(4), 283-299.

Andersson, U., Björkman, I., \& Forsgren, M. (2005). Managing subsidiary knowledge creation: The effect of control mechanisms on subsidiary local embeddedness. International Business Review, 14(5), 521-538.

Andersson, U., Forsgren, M., \& Holm, U. (2001). Subsidiary embeddedness and competence development in MNCs a multi-level analysis. Organization Studies, 22(6), 1013-1034.

Andersson, U., Forsgren, M., \& Holm, U. (2002). The strategic impact of external networks: Subsidiary performance and competence development in the multinational corporation. Strategic Management Journal, 23(11), 979-996.

Andersson, U., Gaur, A., Mudambi, R., \& Persson, M. (2015). Unpacking interunit knowledge transfer in multinational enterprises. Global Strategv Journal, 5(3), 241-255.

Armstrong, J. U. S. T., \& Overton, T. (1977). Estimating nonresponse bias in mail surveys. Journal of Marketing Research, 14, 396-402.

Arora, A., \& Gambardella, A. (1990). Complementarity and external linkages: The strategies of the large firms in biotechnology. The Journal of Industrial Economics, 38(4), 361-379.

Athreye, S., Batsakis, G., \& Singh, S. (2016). Local, global, and internal knowledge sourcing: The trilemma of foreign-based R\&D subsidiaries. Journal of Business Research (forthcoming). doi:10.1016/j.jbusres.2016.02.043

Athey, S., \& Stern, S. (1998). An empirical framework for testing theories about complimentarity in organizational design (No. w6600). Cambridge, MA: National Bureau of Economic Research.

Audretsch, D. B., Menkveld, A. J., \& Thurik, A. R. (1996). The decision between internal and external R \& D. Journal of Institutional and Theoretical Economics (JITE)/Zeitschrift für die gesamte staatswissenschaft, 152(3), 519-530.

Bartlett, C. A., \& Ghoshal, S. (1999). Managing across borders: The transnational solution (Vol. 2). Boston, MA: Harvard Business School Press.

Bas, C. L., \& Sierra, C. (2002). 'Location versus home country advantages' in R\&D activities: Some further results on multinationals' locational strategies. Research Policv. 31(4), 589-609.

Belderbos, R., Carree, M., \& Lokshin, B. (2006). Complementarity in R\&D cooperation strategies. Review of Industrial Organization, 28(4), 401-426.

Birkinshaw, J., \& Hood, N. (2000). Characteristics of foreign subsidiaries in industry clusters. Journal of International Business Studies, 31(1), 141-154.

Burt, R. S. (1993). The social structure of competition. Explorations in Economic Sociology, $65,103$.

Cantwell, J. (1995). The globalisation of technology: What remains of the product cycle model? Cambridge Journal of Economics, 19, 155-174.

Cantwell, J., \& Mudambi, R. (2005). MNE competence-creating subsidiary mandates. Strategic Management Journal, 26(12), 1109-1128. 
Carree, M., Lokshin, B., \& Belderbos, R. (2011). A note on testing for complementarity and substitutability in the case of multiple practices. Journal of Productivity Analvsis, $35(3), 263-269$.

Cassiman, B., \& Veugelers, R. (2006). In search of complementarity in innovation strategy: Internal R\&D and external knowledge acquisition. Management Science, 52(1), 68-82.

Criscuolo, P. (2009). Inter-firm reverse technology transfer: The home country effect of R\&D internationalization. Industrial and Corporate Change. 18(5), 869-899.

Criscuolo, P., Narula, R., \& Verspagen, B. (2005). Role of home and host country innovation systems in R\&D internationalisation: A patent citation analysis. Economics of Innovation and New Technologv. 14(5), 417-433.

D’Agostino, L. M., \& Santangelo, G. D. (2012). Do overseas R\&D laboratories in emerging markets contribute to home knowledge creation? Management International Review, 52(2), 251-273.

Di Minin, A., \& Palmberg, C. (2007). Why is strategic R\&D (still) homebound in a globalized industry? The case of leading firms in wireless telecom. Industry Studies Working Paper No. 2007-12.

Figueiredo, P. N. (2011). The role of dual embeddedness in the innovative performance of MNE subsidiaries: Evidence from Brazil. Journal of Management Studies, 48(2), 417-440.

Foss, N. J., \& Pedersen, T. (2002). Transferring knowledge in MNCs: The role of sources of subsidiary knowledge and organizational context. Journal of International Management, $8(1), 49-67$.

Gammelgaard, J., \& Pedersen, T. (2010). Internal versus external knowledge sourcing of subsidiaries and the impact of headquarters control. In U. Andersson \& U. Holm (Eds.), Managing the contemporary multinational. The role of headquarters (pp. 211-230). Cheltenham: Edward Elgar.

Ghemawat, P., \& Spence, A. M. (1985). Learning curve spillovers and market performance. The Ouarterlv Journal of Economics, 100, 839-852.

Grant, R. M. (1996). Toward a knowledge-based theory of the firm. Strategic Management Journal, 17, 109-122.

Hagedoorn, J., \& Cloodt, M. (2003). Measuring innovative performance: Is there an advantage in using multiple indicators? Research Policy, 32(8), 1365-1379.

Hagedoorn, J., \& Frankort, H. T. (2008). The gloomy side of embeddedness: The effects of overembeddedness on inter-firm partnership formation. Advances in Strategic Management, 25, 503-530.

Hair, J., Anderson, R. E., Tatham, R. L., \& Black, W. (1998). Multivariate data analysis with readings. Englewood Cliffs, NJ: Prentice-Hall.

Hansen, M. T. (2002). Knowledge networks: Explaining effective knowledge sharing in multiunit companies. Organization Science, 13(3), 232-248.

Hervas-Oliver, J. L., \& Albors-Garrigos, J. (2009). The role of the firm's internal and relational capabilities in clusters: When distance and embeddedness are not enough to explain innovation. Journal of Economic Geography, 9(2), 263-283.

Kang, K. H., \& Kang, J. (2009). How do firms source external knowledge for innovation? Analysing effects of different knowledge sourcing methods. International Journal of Innovation Management, 13(1), 1-17.

Kogut, B., \& Singh, H. (1988). The effect of national culture on the choice of entry mode. Journal of International Business Studies, 19(3), 411-432. 
Kogut, B., \& Zander, U. (1996). What firms do? Coordination, identity, and learning. Organization Science, 7(5), 502-518.

Kumar, R., \& Nti, K. O. (1998). Differential learning and interaction in alliance dynamics: A process and outcome discrepancy model. Organization Science, 9(3), 356-367.

Lee, C., Lee, K., \& Pennings, J. M. (2001). Internal capabilities, external networks, and performance: A study on technology-based ventures. Strategic Management Journal. 22(6-7), 615-640.

Meyer, K. E., Mudambi, R., \& Narula, R. (2011). Multinational enterprises and local contexts: The opportunities and challenges of multiple embeddedness. Journal of Management Studies, 48(2), 235-252.

Michailova, S., \& Mustaffa, Z. (2012). Subsidiary knowledge flows in multinational corporations: Research accomplishments, gaps, and opportunities. Journal of World Business, 47(3), 383-396.

Milgrom, P., \& Roberts, J. (1990). The economics of modern manufacturing: Technology, strategy, and organization. The American Economic Review, 80(3), 511-528.

Milgrom, P., \& Roberts, J. (1995). Complementarities and fit strategy, structure, and organizational change in manufacturing. Journal of Accounting and Economics, 19(2), 179-208.

Monteiro, L. F., Arvidsson, N., \& Birkinshaw, J. (2008). Knowledge flows within multinational corporations: Explaining subsidiary isolation and its performance implications. Organization Science, 19(1), 90-107.

Mudambi, R., \& Pedersen, T. (2007). Agency theory and resource dependency theory: Complementary explanations for subsidiary power in multinational corporations. Bridging IB theories, constructs, and methods across cultures and social sciences. Basingstoke: Palgrave Macmillan.

Nell, P. C., Ambos, B., \& Schlegelmilch, B. B. (2011). The MNC as an externally embedded organization: An investigation of embeddedness overlap in local subsidiary networks. Journal of World Business, 46(4), 497-505.

Nell, P. C., \& Andersson, U. (2012). The complexity of the business network context and its effect on subsidiary relational (over-)embeddedness. International Business Review, 21(6), 1087-1098.

Nielsen, B. B. (2005). The role of knowledge embeddedness in the creation of synergies in strategic alliances. Journal of Business Research, 58(9), 1194-1204.

Nunnally, J. C., Bernstein, I. H., \& Berge, J. M. T. (1967). Psychometric theory. New York, NY: McGraw-Hill.

Patel, P., \& Pavitt, K. (1991). Large firms in the production of the world's technology: An important case of "non-globalisation". Journal of International Business Studies, 22, 1-21.

Patel, P., \& Vega, M. (1999). Patterns of internationalisation of corporate technology: Location vs. home country advantages. Research Policv. 28(2). 145-155.

Pearce, R. D., \& Singh, S. (1992). Globalizing research and development. London: Macmillan.

Phene, A., \& Almeida, P. (2008). Innovation in multinational subsidiaries: The role of knowledge assimilation and subsidiary capabilities. Journal of International Business Studies, 39(5), 901-919.

Podsakoff, P. M., \& Organ, D. W. (1986). Self-reports in organizational research: Problems and prospects. Journal of Management, 12(4), 531-544.

Sampson, R. C. (2007). R\&D alliances and firm performance: The impact of technological diversity and alliance organization on innovation. Academv of Management Journal, 50(2), 364-386. 
Santangelo, G. D. (2012). The tension of information sharing: Effects on subsidiary embeddedness. International Business Review, 21(2), 180-195.

Saxenian, A., \& Hsu, J. Y. (2001). The silicon valley-Hsinchu connection: Technical communities and industrial upgrading. Industrial and Corporate Change, 10(4), 893-920.

Uzzi, B. (1997). Social structure and competition in interfirm networks: The paradox of embeddedness. Administrative Science Ouarterlv, 42, 35-67.

Veugelers, R. (1997). Internal R \& D expenditures and external technology sourcing. Research Policv. 26(3), 303-315.

Yamin, M., \& Otto, J. (2004). Patterns of knowledge flows and MNE innovative performance. Journal of International Management, 10(2), 239-258.

Zhao, M. (2006). Conducting R\&D in countries with weak intellectual property rights protection. Management Science, 52, 1185-1199. 